\title{
NEZNÁMÉ LISTY JOSEFA STEPLINGA MAXIMILIANU HELLOVI
}

\author{
JOSEF SMOLKA - HANS ULLMAIER
}

\section{JOSEPH STEPLING'S PREVIOUSLY UNKNOWN LETTERS TO MAXIMILIAN HELL}

This contribution includes the text and commentary on three letters, which Joseph Stepling wrote to Maximilian Hell. Two of these letters were written in 1757, one in 1759, and all were discovered in the archive of the Viennese university astronomical observatory. They fall into a period covered by Stepling's correspondence reprinted in the Litterarum commercium (Wratislaviae 1782), which makes it an interesting contribution to this subject.

Keywords: Joseph Stepling - Maximilian Hell - scientific correspondence - Enlightenment - eighteenth century

DOI: $10.14712 / 23365730.2018 .52$

Třísté výročí od narození Josefa Steplinga, našeho největšího přírodovědce 18. století, dalo nový podnět k badání o jeho životě a díle. Velikou roli v něm hrála Steplingova vědecká korespondence, která mu byla jedním z hlavních prostředků, jímž si udržoval neustálý kontakt s vývojem evropské vědy. Mezi jeho korespondenty patřil naprríklad Christian Wolf, Leonhard Euler, Rođer Josef Boškovič, Christopher Maire, Nicolas-Louis de Lacaille i řada dalších hvězdných jmen 18. století. Na mnohé z těchto autorit se obracel se svými otázkami sám, jiným korespondentům na dotazy odpovídal a neustále si tak trríbil názory na aktuální vědecké problémy.

Po Steplingově smrti se stal držitelem jeho pozůstalosti Stanislav Vydra, a tak se mlčky předpokládalo, že soubornou korespondenci vydal. ${ }^{1}$ Trochu nejasná byla jen skutečnost, proč vyšla ve Vratislavi. Že by pražští tiskaři listy bývalého jezuity odmítli? Poslední bádání však ukázalo, že celá věc je složitější: Vydra byl nucen Steplingovy listy předat - kdo je však skutečně vydal, s jistotou nevíme. Naší hypotézou je Steplingův prŕiznivec hrabě Nostic. Tato korespondence obsahuje na více než šesti stech stranách sto deset listů z let 1743-1778 a jedno drobné pojednání. Když jsme se začali tímto poměrně rozsáhlým souborem blíže zabývat, museli jsme konstatovat, že vykazuje řadu mezer. Nejnápadnější to bylo u dvou korespondentů s větším množstvím listů, u würzburského Franze Hubertiho (1715-1789) a vídeňského Maximiliana Hella (1720-1792). Vydaná korespondence s Hubertim čítá dvacet dva listů, je však autorsky velmi nevyvážená: Huberti jich napsal

1 Litterarum commercium eruditi cum primis argumenti, Wratislaviae 1782. Jeden z exemplářů klementinské Národní knihovny (sign. 75 C 221) byl nedávno zdigitalizován a je dnes na internetu pohodlně př́stupný: http:// www.manuscriptorium.com/apps/index.php?envLang=cs\#search <ověřeno 9. 9. 2018>. 
devatenáct, zatímco Stepling odpověděl jen třikrát. Tak tomu ve skutečnosti jistě nebylo, nebot' velká část jejich korespondence měla obchodní charakter - Huberti Steplingovi obstarával nákup zařízení pro pražskou hvězdárnu, mimo jiné až z Anglie, a lze proto předpokládat, že na ní byl Stepling vysoce zainteresován a jistě pravidelně odpovídal. Snažili jsme se alespoň některé $\mathrm{z}$ těchto chybějících listů nalézt $\mathrm{v}$ archivu univerzity ve Würzburgu, kde Huberti působil. Pátral v něm prvý ze spoluautorů tohoto př́spěvku, bohužel ale neuspěl: Hubertiho pozůstalost během druhé světové války beze stopy zmizela.

Podobně tomu bylo i s Hellem. Jeho vydaná korespondence se Steplingem vykazuje sedm listů: pět z nich napsal Hell a jen dva Stepling. ${ }^{2}$ I zde byl učiněn pokus nalézt chybějící Steplingovy listy. Druhý ze spoluautorů hledal v archivu vídeňské univerzitní hvězdárny, jejímž byl Hell ředitelem, a byl štastnější. Hell si zřejmě potrpěl na pořádek - dával si každý list opsat. $\mathrm{V}$ těchto opiseh byly objeveny tři Steplingovy neznámé listy. ${ }^{3}$ Prvý pochází z roku 1757 a korespondenci obou pánů vlastně otevírá.

Stepling Hellovi, 30. Januarii $1757^{4}$

In margine: A Stepling, petit comercium literarum

Petit horologia et tubum Neuthon[ianum]

\section{Reverende P[ater] (!) in Ch[ri]sto Pater (!)}

Ephemerides a $R[$ everend $]$ o $P[$ atre $]$ ad annum 1757 editas, sane praestantes non sine voluptate vidi, et pervolvi, gratulorque $R$ [everendo] $P[$ atri] de initio illo, rebus astronomicis utilissimo, et Societati nostro perquam honorifico. Quod spero ardentissime est ut cum $R$ [everendo] $P[$ atre $]$ comercium literarum astronomicum inire possim. Sicque etiam voluntati Patris Frantz facere satis. At enim ante fieri non potest, quam adcuratas instituere valeam observationes, id ce[te]ris $P[a t] r i$ Bleiweis scripsi, ut it quaedam ad observandum necessaria fieri mihi curet. Respondit $P[$ ater] Bleiweis se negotium hocce $R[$ everend $]$ o P [atri] Frantz commisisse, oratum cupio, quo negotium sibi commissum haud gravate adcuret, ac duo horologia oscillatoria ad modum Grahamianorum (si putat adcurata Viennae effici posse) parari faciat, nec non tubum reflectentem a D[omino] Schulzio non quidem 8 sed tantum 3 interim pedum, cum facilius et commodius tractari possit hic, ac nihilominus ordinario 30, ne ultra pedum aequi valeat, adeoque eo, et Callisto satellitum Jovis, ac forsan etiam Saturni observari possint. Quaeso velit $R$ [everendus] Pater paucis saltem quae sit circa hac mens $R$ [everendi $] P[$ atris $]$ Frantz ac etiam $R[$ everendae $] P[a] t[$ er $]$ ni[ta]ti V[estr]ae significare, qui me benevolentiae pristinae ac Sanctae ad aram memoriae impense comendo, ac maneo $R[$ everendo] $P[$ atri]. Pragae 30. Januarii 1757 infimus servus in Christo

2 Blíže o této vydané korespondenci srov. Josef Smolka - Martin Šolc, Maximilian Hell und Prager Astronomie, in: Festkolloquium und Fachtagung 250 Jahre Universitätssternwarte Wien, Communications in Asteroseismology, vol. 149 (Dezember 2008), s. 21-30.

3 Hellova pozůstalost je dnes zdigitalisována, není však snadné se v ní orientovat. Za laskavou kolegiální pomoc při bádání vděči autoři pracovníku tohoto archivu, p. Günteru Bräuhoferovi.

4 Wien, Archiv der Universitätssternwarte, Astr._NL_2 155_Rever._Christo_Pater-2-16-05.jpg, s. 61. 
Výše uvedený text tedy představuje Steplingův prvý list, kterým zahajuje svou korespondenci s ředitelem vídeňské univerzitní astronomické observatoře Maximilianem Hellem. Stepling byl o čtyři roky starší, a tak mohl svého jezuitského kolegu ke korespondenci snadno vyzvat. Podnětem mu byl prvý svazek právě vyšlých Hellových efemerid na rok 1757. Stepling mu k jejich vydání blahopřeje a dodává, že je to velmi užitečná pomůcka, která činí čest nejen jemu, ale zároveň i jezuitskému rádu. Současně Hellovi nabízí vzájemnou korespondenci: vyhovělo by se tak i prání otce Franze. Také jej informuje, že prostřednictvím otce Bleiweise objednal ve Vídni dvoje kyvadlové hodiny grahamovského typu, tj. hodiny opatřené kotvou, a dalekohled (newtonský reflektor), aby mohl pozorovat Jupiterův měsíc Callisto, př́ípadně i satelity Saturnovy. Nechce však ten největší, za nejpohodlnější považuje dalekohled třístopý. ${ }^{5}$ Prosí, aby tuto objednávku Hell i Franz (kterému ji dal Bleiweis $\mathrm{k}$ vyř́izení) posoudili.

V textu dopisu vystupují dvě méně známé osobnosti: Joannes Bleiweis (1702-1760), rodák z Jaroměře a jezuita, který byl v letech 1734-1740 v klementinské koleji postupně profesorem poetiky, etiky, filozofie a morální teologie. Stepling měl tedy prŕležitost seznámit se s ním možná už brzy po svém vstupu do rádu, jistě - a blíže - pak v roce 1744, kdy oba opět v Klementinu současně působili. Od roku 1745 byl Bleiweis delegován do Vídně, kde působil až do své smrti jako zástupce jezuitského řádu u císařského dvora. $Z$ kontextu je patrné, že Stepling měl ke staršímu Bleiweisovi absolutní důvěru, pravděpodobně od něj dostával i informace o událostech v hlavním městě monarchie. ${ }^{6}$

Druhou jmenovanou osobností je Joseph Franz (1704-1776), ${ }^{7}$ jezuita, který stál blízko císařské rodiny, byl mimo jiné preceptorem Josefa II. V letech 1744-1773 byl správcem matematického muzea ve Vídni. Když byla v témže roce 1744 na tamní univerzitě zřízena stolice experimentální fyziky, byl Franz jmenován jejím profesorem a začal s veřejnými demonstracemi fyzikálních experimentů. Je velmi pravděpodobné, že když obdobné pokusy započal v roce 1745 na pražské medicínské fakultě profesor Jan Antonín Scrinci (a po něm zahájili výuku experimentální fyziky v Klementinu i jezuité), ${ }^{8}$ sledovali jen př́klad vídeňského kolegy. V roce 1752 se stal Franz ve Vídni direktorem filozofických studií podobně jako Stepling v Praze. V roce 1759 byl však na žádost van Swietena $\mathrm{z}$ této funkce odvolán. $Z$ listů s jinými osobami vyplývá, že si Stepling s Franzem dopisoval, v jeho vydané korespondenci se nám však žádný list nezachoval. Kardinálním svědectvím jejich blízkého vztahu je ale překrásný barokně provedený etalon vídeňského sáhu ve sbírkách pražského Národního technického muzea. $Z$ nápisů na něm vyplývá, že jej po tereziánské reformě délkových měr v roce 1756 obstaral právě Franz a zřejmě jej nechal zaslat Steplingovi do Prahy. Jsou na něm zachyceny všechny převodní vztahy mezi novým vídeňským

5 Tento Steplingův požadavek dovedeme pochopit. Svá prvá astronomická pozorování, zatmění Měsíce, konal $\mathrm{v}$ roce $1748 \mathrm{~s}$ dalekohledem desetistopým, jak se dozvídáme hned v prvé větě jeho prvé tištěné publikace (srov. Observatio eclipsis Lunae, octava Augusti die A. 1748 Pragae..., in: Nova Acta Eruditorum, Lipsiae 1748, mensis Septembris, s. 518). Manipulace s třímetrovým tubusem nepatřila asi k nejpohodlnějším.

6 Blíže k jeho biografickým datům srov. Ivana ČornejovÁ - Anna FeChTNERovÁ, Životopisný slovnik pražské univerzity. Filozofická a teologická fakulta 1654-1773, Praha 1986, s. 30-31.

7 Psaní jeho př́imení není jednotné, často se vyskytuje i „Frantz“. Nejednou je použil i Stepling. Přidržujeme se však formy bez „t“, kterou uvádí Wurzbachův slovník.

8 Podrobněji o tom srov. Cassian HallaschKa, Versuch einer geschichtlichen Darstellung dessen, was an der Karl-Ferdinandischen Universtät zu Prag in der Experimentalphysik gearbeitet wurde; welches das Entstehen, der Fortgang und die Aufnahme des k.k. physikalischen Musäums gewesen, und welches der heutige Zustand desselben sey, Prag 1818, s. 13nn. 
sáhem a loktem a dosud uživanými mírami v západní části habsburské monarchie. Škoda, že je dosud jen $v$ depozitáři muzea a není vystaven. ${ }^{9}$

Podobně jako Stepling, ani Franz se dosud nedočkal své životopisné monografie. Základní informace o něm přináší Wurzbach, ${ }^{10}$ naposledy o něm psala Nora Pärrová. ${ }^{11}$ Franzův filozofický profil na základě pojednání o metafyzice, které napsal pro Josefa II., podává výstižně Derek Beales. ${ }^{12}$

Určitého komentáře si zasluhuje také pojem Callisto, který se zde v textu vyskytuje. Je to po Ganymedovi druhý největší ze čtyř měsíců, které objevil Galilei, když v roce 1610 poprvé použil dalekohled ke zkoumání hvězdného nebe. Od Jupitera je ze všech čtyř měsíců nejvíce vzdálen. K pozorování jeho zákrytů se Stepling nerozhodl náhodně, předcházela tomu celá řada událostí. V roce 1748 , na samém počátku své vědecké kariéry, pozoroval Stepling 8. srpna zatmění Měsíce. Bylo to z podnětu berlínské akademie věd, která chtěla pro novou mapu Německa znát přesnou geografickou délku Prahy. Své výsledky zaslal do Berlína, odkud obratem obdržel list napsaný hned 31. srpna a podepsaný ředitelem matematické tř́́dy Leonhardem Eulerem a stálým sekretářem této akademie Jeanem Henrim Samuelem Formeyem. Děkují mu za výsledky pozorování Měsíce, litují ale, že nepozoroval i zatmění Slunce, které považují pro určení rozdílu délek Berlína a Prahy za výhodnější. Dávají Steplingovi k dispozici údaje naměřené v Berlíně, ale hlavně - přimlouvají se a dokonce žádají, aby nadále pozoroval Jupiterovy satelity, které umožňují daleko přesnější určení polohy Prahy, ${ }^{13}$ a výsledky jim opět zaslal. Stepling se však k těmto pozorováním dostal až o řadu let později. Zdá se, že pro ně neměl potřebné vybavení. Své výsledky - jak uvidíme níže - také nepředal berlínské akademii, ale Hellovi a poté i pařížskému de Lacailleovi.

Vrat'me se však k Hellově odpovědi na Steplingův prvý list - byla poměrně stručná, zato však velmi rychlá, nese datum 9 . února 1757 . Je známá, byla už uveřejněna. ${ }^{14}$ Vyrozumíváme z ní, jak si Stepling opatřil první svazek Hellových efemerid: když se dozvěděl o zahájení jejich vydávání, obrátil se přímo na vídeňského vydavatele Trattnera. Hell rád přijímá Steplingovu výzvu ke korespondenci, dosud si ale s nikým nedopisuje. S upř́mnou otevřeností sděluje i důvod - dvůr mu prý dosud nestanovil, kolik za korespondenci může utratit. To nás upozorňuje na moment, $\mathrm{k}$ němuž jsme dosud př́liš nepřihlíželi - posílání listů bylo tehdy daleko dražší než v pozdější době. Hell sděluje, že vyř́íil pozdrav otci Franzovi, od něhož se dozvěděl, jak jej má rád a jak je Stepling významnou osobností.

Zde se musíme chvíli pozastavit. Toto místo se zdá naznačovat, že si Stepling s Franzem, který byl o dvanáct let starší, nejen dopisoval, ale že se i osobně setkali. V řádovém curriculu vitae nic nenasvědčuje tomu, že by Stepling byl někdy ve Vídni, a tak se snad

9 Národní technické muzeum v Praze, inv. č. 17196.

10 Constant WurzBach, Biographisches Lexikon des Kaiserthums Oesterreich, IV, Wien 1858, s. $342-343$.

11 Nora PärR, Maximilian Hell und sein wissenschaftliches Umfeld im Wien des 18. Jahrhunderts, Nordhausen 2013, s. 15-21.

12 Derek Beales, Joseph II., I, In the Shadow of Maria Theresa 1741-1780, Cambridge 1987, s. 46-48.

13 „Si eclipses satellitum Iovis, cuiusmodi nunc plurimae sunt nobis conspicuae, pari solertia observare vellis, multo certiores de vero situ vestrae urbis reddemur. Quod onus si suscipere haud gravaris, enixe rogamus...", Litterarum commercium..., s. 275.

14 Srov. tamtéž, s. 450-452. 
můžeme obrátit do jeho privátní sféry. Svého času jsme zjistili, že Steplingovým kmotrem, po němž dostal obě prvá křestní jména, byl Josef František Václav hrabě Bruntálský z Vrbna (1675-1755), ${ }^{15}$ společensky jedna z nejvýše postavených osobností Českého království. Byl nejen císařským tajným radou a členem válečné rady, ale i vicekancléřem české dvorské rady. Vyslovili jsme přitom domněnku, že z tohoto rodu pocházela i jeho matka Blandina. ${ }^{16}$ Je možné si představit, že Stepling mohl spolu s matkou svého kmotra ve Vídni navštívit, mohl jet třeba i na jeho pohřeb v roce 1755. Existuje však i jiná možnost: Franz byl císařovnou pověřen tím, aby zkontroloval, jak je olomoucká univerzita vybavena pro výuku experimentální fyziky. ${ }^{17}$ Tato vizitace skutečně proběhla a univerzita dostala na základě jejích výsledků mimořádnou dotaci na nákup fyzikálních př́strojů. S podobným posláním přijel Franz i do Prahy. ${ }^{18}$

Vrat'me se k místu, kde Hell sděluje, že vyř́ílil Franzovi Steplingův pozdrav. Když mu připomněl, že se má postarat o nákup dalekohledu pro Steplinga, dozvěděl se, že Franz préenesl tento úkol na otce Bleiweise. Ten je prý ovšem dlouhodobě mimo domov (, ,longiori tempore a domo abfore"), a tak Hell rezignovaně sděluje, že se úkolu poř́́dit pro Steplinga dalekohled ujme sám.

$$
* * *
$$

Stepling vzal obsah předchozího listu zřejmě na vědomí, nijak ale nereagoval, popravdě řečeno nebylo mnoho ani na co. V Praze nebyla ostatně $\mathrm{v}$ jarních měsících př́liš povzbudivá situace, nebot' ji ohrožovala agrese pruských vojsk. Osazenstvo Klementina bylo evakuováno do Liběšic na Litoměřicku, kde měli jezuité svou letní rezidenci. ${ }^{19}$ Určité rozuzlení znamenala až vítězná bitva u Štěrbohol, k níž došlo 6. května 1757. Příští dopis je proto opět dopisem Hellovým - i ten je znám, figuruje v souborném vydání Steplingovy korespondence. ${ }^{20}$ Je datován dnem 15. července 1755 . Začíná tím, že se Hell dozvídá, že válečné bouře utichly a silnice do Prahy jsou opět volné. To Hell potřeboval. Sděluje totiž Steplingovi další dobré novinky: čtyřstopý newtonský dalekohled, ${ }^{21}$ zhotovený vídeňským Schulzem, má už Hell u sebe. Koupil jej za 70 rýnských a předá jej otci Bleiweisovi, aby zařídil jeho bezpečnou přepravu do Prahy. Hell tento př́stroj po tři měsíce zkoušel a srovnával dosažené výsledky s těmi, které mu dával jeho rovněž čtyřstopý dalekohled anglické výroby. Sledoval zákryty prvých tří Jupiterových měsíců a rozdíl prý nebyl větší než 30 sekund. Při pozorování Saturnových satelitů byl nový dalekohled dokonce lepší. Ke srovnání dokonce nasadil i čtrnáctistopý dioptrický dalekohled Marinoniho. Hell už má prý

15 Josef Smolka, K pưvodu Josefa Steplinga, Dějiny věd a techniky 46, 2013, s. 151-163, zde s. 154.

16 Nově se dnes domníváme, že po smrti Steplingova otce a návratu matky do Prahy v roce 1718 mohli bydlet v dnešní Valdštejnské ulici č. 8, ve Fürstenberském paláci, kde je v současné době polské velvyslanectví. Hrabata z Vrbna jej získali do držení v roce 1714. Malý Josef by měl odtud do malostranského gymnázia (na rohu dnešní Sněmovní a Thunovské ul.), které navštěvoval, doslova pár kroků. K tomu srov. též Pavel VLČEK a kol., Umélecké památky Prahy - Malá Strana, Praha 1999, s. 249-250.

17 Srov. Václav NeŠPOR, Déjiny olomoucké university, Olomouc 1947, s. 62.

18 Josef Haubelt, České osvicenství, Praha 2004, s. 250n.

19 Stepling zde v této době na blízké hoře Jeleč (619 m n. m.) reprodukoval Pascalův historický pokus, který dokázal, že výše rtut'ového sloupce v Torricelliho trubici je závislá na nadmořské výšce. K tomu srov. Joseph Stepling, Miscellanea philosophica, Pragae 1759.

20 Litterarum commercium, s. 453-455.

21 Hell tedy obstaral dalekohled dlouhý čtyři stopy, ačkoli Stepling si přál výslovně tř́stopý. Hell tuto změnu nikterak nevysvětlil. Stepling ji přijal v př̌ištím dopise rovněž bez jakéhokoli komentáře. 
u sebe také jedny objednané hodiny, druhé by měly být hotovy v ř́inu. Sděluje pak cenu za jedny, mělo by to být 100 rýnských, ale přesvědčuje Steplinga, jak je to výhodná cena. Na konci dopisu vyjadřuje Hell přesvědčení, že Stepling bude 30. července pozorovat měsíční zatmění a že mu sdělí své výsledky.

Tento list předvádí Hella jako úspěšného manažera, který se dovedl postarat o naplnění a v prŕípadě dalekohledu i o odzkoušení Steplingovy objednávky. Bleiweis by to nedokázal zcela jistě a ani Franz by asi nebyl tak perfektní.

$$
* * *
$$

Steplingovu reakci na tento list jsme dosud neznali. Přináší ji až časově druhý z nově objevených dopisů. Odpověd' je to poměrně rychlá, nese datum 28. července.

Stepling Hellovi, 28. Julii $1757^{22}$

In margine: A Stepling

Scholae intermissae Pragae

\section{$R[$ evere $]$ nde $P[$ ater $]$ in $C h[$ ris $]$ to Pater (!)}

Literas $R$ [everend] $i$ P[atris] 15 hujus ad me conscriptas $n[$ on] sine voluptate legi, continuoque rescripsissem, nisi negotia quaedam molesta multum, et necessaria moras injecistente intellexi ex illis literis, quae $R$ [everendus] $P[$ ater] benevole curavit, et quam exacto, diuturnoque examine, tubum reflectentem examinavit, gratiam idcirco maximam $R[$ everend] ae V[estr]ae nunc quidem ago, referam vero etiam atque, quae adhuc curanda sunt, $R[$ everend]o $P[$ atr $]$ i majorem in modum commendata cupio. 70 Rhenenses lubens ubi tubum accepero numerari faciam artifici. Superest ut aliud beneficium superioribus adjungendum a $R[$ everend]o $P[$ atre $]$ magnis precibus copetam. Scio quidem $R[$ everendum $] P[$ atrem $]$ astronomicis, mechanicisque occupatissimum esse, sed nolo illud $P[$ atri] Bleiweis comittere. Oro igitur: velit $R$ [everendus] $P[$ ater] non gravare e $R$ [everendo] $P[$ atre $]$ Frantz (quem amicissime adsaluto) quaerere nomine meo, an scholae et phylosophiae, et humaniores in Triurbe nostra differendae sint, in annum sequentem scholasticum, et ita quidem ut discipuli in suis classibus persistant una cum professoribus, materiaque jam hoc anno usque ad Aprilem inclusive tradita denuo repetantur, ab ovo. Istud ego quidem non obstantibus quibusdam rationibus, et dificultatibus necessarium esse puto. Nam schola phylosophicorum adiri nondum possunt, nec poterunt, quod adhuc laesis militibus implentur. Humaniores in collegio nostro hac hebdomada coeptae sunt, sed nec omnes iuvenes admitti possunt, ob loci angustias, nec tempus expleri, quo aliis in scholis morantur eo, quod alii, aliis locum dare coguntur. Nec res serio agitur ita, ut quae jam neglecta sunt, per 3 menses compensari, et quae nunc tradenda per se sunt recte tradi posse nullatenus credam. In Domo professa, et Nova Urbe, nondum resumtae sunt humaniores literae, itaquoad evitandum omnem in literarum profectu hiatum, confusionemque optimum foret, annum hunc repetere anno sequente idque uti Augusta decerneret. Ita pro phylosophis et altioribus scholis et humanioribus

22 Wien, Archiv der Universitätssternwarte, Astr._NL_2 155_Rever._Christo_Pater-2-16-05.jpg, s. 61, a Astr. NL_2 155_Rever._Christo_Pater_2-17-05.jpg, s. $6 \overline{2}$. 
nominatim in Triurbe et locis illis extra Triurbem, ubi scholae mensibus aliquot vacabant, necessarium plane esset. Quaeso igitur, $R[$ everendum $] P[a t r e m]$ mentem $R[$ everendi] $P[$ atris $]$ Frantz exquirat, atque de ea me quantocyus certiorem reddat, nam undique ad me concurritur, et quid agendum quaeritur nec tamen certi, quod respondeam interogantibus. Scio quidquam, nisi quod D[ominus] Director Iuris collegia hujus anni, nunc sequente rependa esse, iis antedixerit, qui rogandi causa ad illum adierunt. Idque Vienna sibi perscriptum esse et esse Augustae voluntatem. Ego vero horum nihil scio, et a $R[e-$ verendo $] P[$ atre $]$ Directore Viennensi destituor, penitus. Verum manum de tabula: ignoscat $R[$ everend $]$ us $P[$ ater $]$ nam et negotiis, et prolixo literarum sermone incomodo. Comendo me inpensissime pristino affectui, et Sacrae ad Ara memoriae et maneo R[everend]i P[atris] A. G. /??/ Pragae 28. Julii 1757 servus in Christo

Josephus Stepling S.J.

Steplingův dlouhý list se rozpadá na dvě části. $\mathrm{V}$ prvé z nich je omluva za pozdní odpověd' - možná trochu nadbytečná, vždyt' na dopis psaný ve Vídni se z Prahy odpovídá už za třináct dnů - a poděkování za obstarání newtonského dalekohledu i za jeho důkladné odzkoušení. Dalekohled do Prahy zřejmě v pořádku dorazil, Vydra jej uvádí v seznamu př́istrojů klementinské hvězdárny. ${ }^{23}$ Stepling je také spokojen s cenou 70 rýnských a je hotov ji po obdržení príistroje okamžitě vyplatit. Tato astronomická část listu je však překvapivě velmi stručná.

Steplingova pozornost je $\mathrm{v}$ této chvíli upřena především $\mathrm{k}$ výuce na filozofické fakultě, ale i na dalších školách, která byla vojenskými událostmi krutě narušena a má problémy až dosud: ,školy jsou plné raněných voják ơ “, píše Stepling. Nechce obtěžovat otce Bleiweise, a proto se obrací s prosbou na Hella a žádá jej, aby otci Franzovi předložil problém pražského trojměstí i jeho okolí, kde se na školách všech stupňủ několik měsíců neučilo. Je jasné, proč chtěl Stepling konzultovat svůj další postup s Franzem - byl ve Vídni ve stejné funkci direktora filozofických studií, jako byl Stepling v Praze. Nejasné ale je, proč se na něj Stepling neobrátil přímo sám a volil složitější cestu přes Hella. Stepling se domnívá, že by všichni žáci měli zůstat ve tř́́dách, v nichž byli i v minulém školním roce, a látka by se měla opakovat. Franz by podle něj měl tuto záležitost předložit císařovně a ta by měla ve smyslu Steplingova stanoviska rozhodnout (,,hunc annum repetere anno sequente idque uti Augusta decerneret $\left.{ }^{\star *}\right)$. Stepling o to žádá velice naléhavě, i když ví, že jeho kolega, direktor právního studia, už situaci vyřešil, a to rovněž opakováním ročníku. Na Steplinga - jak naznačuje - se přitom obrací řada lidí, kteř́ jej žádají v této věci o radu.

Stepling se nám v tomto listě jeví v novém světle, problémy související s jeho funkcí direktora filozofického studia se $\mathrm{v}$ jeho korespondenci téměř nevyskytují. ${ }^{24}$ Nejen že sám nerozhodl, ale zdá se, že se neradil ani s řádovými ani světskými funkcionáři univerzity rektorem byl tehdy Jan Antonín Scrinci, filozofickým děkanem Josef Jüngling. Neobrátil se přitom na žádný pražský ani český úřad, nenapsal ale ani císařovně, ačkoli od ní očekával

23 Mezi několika dalekohledy figuruje tento přístroj na prvém místě. Vydra o něm napsal: „Tubus Newtonianus Vienna curis Cl. Hellii missus; et cum Anglicano (cuius vir hic summus utitur) collatus." Stanislaus WydRA, Vita admodum reverendi ac magnifici viri Josephi Stepling..., Prage 1779, s. 28.

24 Výjimkou je Steplingův obsáhlý list z dubna 1758 adresovaný jezuitskému generálnímu vikáŕi Joannesu Timonimu do Říma, v němž musel prokazovat, že ortodoxní náboženství se nemusí obávat nové filozofie, která se ve školách vyučuje pod jeho direktorátem. Srov. Litterarum commercium, s. 462-469. 
rozhodnutí - to mohl, vždyt' ta jej do funkce direktora ustavila a Stepling měl k ní i jejímu dvoru veskrze pozitivní vztah. Přesto raději zvolil jakýsi opatrnický obchvat.

$* * *$

Jak celá záležitost dále probíhala, bohužel nevíme, šla zřejmě jinýni cestami, a do Hellovy korespondence se Steplingem se už nepromítla. Hellův prríští dopis z 15. srpna $1758^{25}$ se o tom nezmiňuje ani slůvkem. Referuje o listě, který mu pro Steplinga dal de Lacaille, a sděluje, že do Prahy mohou být odeslány odzkoušené hodiny. Stepling jich bude moci použít při pozorování zákrytů Jupiterových měsíců - Hell závěrem prosí o zaslání těchto výsledků, z nichž lépe určí geografickou délku Prahy i Vídně. Stepling odpovídá už 30. srpna: ${ }^{26}$ nyní, když pominulo nebezpečí pruského vpádu ze Saska, lze hodiny bezpečně poslat. Oboje hodiny se také do Klementina zrrejmě dostaly. Vydra, který se v Steplingově životopise zabývá i vybavením hvězdárny, uvedl, že tu byly patery hodiny. Troje grahamovské a dvoje z nich byly vyrobeny ve Vídni a odzkoušeny Hellem. ${ }^{27}$

Stepling v tomto listě zároveň žádá o konzultaci ke stavbě kvadrantu. Ten, který používá, neodpovídá jeho představám. Nejraději by si chtěl postavit nový sám, neví ale, jakou metodu by měl zvolit. Je si vědom také pracnosti, a proto se táže, zda by nějaký vhodný nebyl ke koupi ve Vídni. A pokud ano, nemá Hell váhat a má jej pro Steplinga zakoupit. Následovala rekordně rychlá odpověd'. Už 9. září $1758^{28}$ Hell sděluje, že předal pražskému povozníkovi dvoje hodiny a přidává několik rad pro jejich uvedení do provozu. Zodpovědět dotaz na kvadrant bylo složitější a Hell byl poněkud rozpačitý. Mnozí Francouzi dávají prý přednost metodě Manfrediho, Hell sám používá raději Marinoniho. Kvadrantů ke koupi je ve Vídni málo a pařížské jsou předražené. Proto by se měl Stepling snad raději porozhlédnout po Anglii. Později se Hell o kvadrantu - a dokonce o kvadrantech, v množném čísle - zmiňuje znovu, a to v dopise ze 4. ledna $1760 .{ }^{29}$ Mluví o nich tak, jako by je Stepling stavěl sám a přeje mu jejich rychlé dokončení. Snad si vzpomněl, že to byla jedna z možností, o níž mu Stepling psal. Do takovéto stavby se pražský astronom ve skutečnosti ale nikdy nepustil. V této věci Hell Steplingovi tedy mnoho nepomohl, to učinil později až jeho korespondent a přítel Franz Huberti z Würzburgu. Po několika listech, v nichž Stepling formuloval své požadavky na nový přístroj (ty bohužel neznáme) a jeho př́itel k nim zaujímal své stranovisko (vše je otištěno v Litterarum commercium), mohl Huberti 18. března 1766 Steplingovi pogratulovat k josefskému svátku a sdělit mu, že se jeho kvadrant začne přezkušovat. ${ }^{30}$

25 Tamtéž, s. 479-481.

26 Tamtéž, s. 484-486.

27 „Horologia grahamiana tria, quorum duo Viennae facta, a Cl. Hellio examinata sunt.“ S. Wydra, Vita ... Josephi Stepling, s. 28.

28 Litterarum commercium, s. 487-489.

29 Tamtéž, s. 499.

30 Jeho konstruktérem byl mechanik - artifex - würzburské univerzity Johann Georg Fellwöck (1728-1810). Jeho zední kvadrant měl 3 stopy a 5 palců. Uvedl to ve svém příspěvku na steplingovské konferenci Hans-Joachim Vollrath, Franz Huberti (1715-1789), Steplingův prítel a korespondent, otištěno zde ve svazku. Podle jeho názoru by měl být tento kvadrant v Klementinu dodnes. Př́itomnost tohoto kvadrantu v Klementinu potvrzuje ve svém soupisu vybavení hvězdárny i Vydra, který vyzdvihuje, že měl veškeré moderní vybavení: „Quadrans radii 3. pedum Parisinarum et 5. digitorum Herbipoli curante Cl. Huberti perfectus. Opus dotibus omnibus, quas hodierni observatores ejusmodi instrumento tribuunt, instructum. " S. Wydra, Vita ... Josephi Stepling, s. 29. 
V další korespondenci už o něm není ani zmínka, takže se můžeme domnívat, že byl brzy poté převezen do Prahy a v Klementinu nainstalován.

Ve snaze dovést ke konci zprávy o novém kvadrantu jsme poněkud předběhli historickou posloupnost, takže se ted' vracíme někam do roku 1759. Př́iští vydaný dopis je opět Hellův, napsal jej 4. ledna $1760 .{ }^{31}$ Je zde zřejmý časový hyát - a právě do něj zapadá třetí nově objevený Steplingův list.

Stepling Hellovi, 28. Decembris $1759^{32}$

In margine: $A$ P $[$ atre $]$ Stepling Praga

$R[$ everende $]$ in $C h[$ ri $]$ sto $P[$ ater $]$ !

Felicissimum anni, quem propediem ordimur, cursum $R$ [everend $]$ o $P[$ atri $]$ sincerissime opto. Et submitto syllabum observationum factorum.

\begin{tabular}{|c|c|c|c|c|}
\hline Junii & 22. & 11. $h$ & $59^{\prime} 39^{\prime \prime}$ & Imersio I. sat [elitis $] J[$ upi $] t[$ eri $]$ \\
\hline Julii & 22. & 10. $h$ & 2. 54 . & Em[ersio $] I I I$. \\
\hline Augu. & 13. & 12. & 43. 44. & $E m[$ ersio $] I I$. \\
\hline Octob. & 9. & 6. & 35. 46 . & Em[ersio $] I I I$. \\
\hline Octob. & 10. & 8. & 20. 3 . & Em[ersio $] I$. \\
\hline
\end{tabular}

Tempora sunt vera, deducta ex correctione horo[ogi]i per correspondas facta. Plures instituere observa[ti]ones tum coeli inconstans facies, tum negotia prohibuere. (s. 423/13)

Dabo tamen operam, ut hoc anno novo plures instituere possim, maxime perfectis quadrantibus, quos hic fieri modo coelum foveat, et negotia directoratus /quo vehementer liberari desidero/, admittant. Si $R$ [everenda] $P$ [aternitas] iam typis edidit suas observationes, oro velit eas mihi submittere, libenter pretium persolvam, quod si adnectere placeret. Imer$s$ [iones] et emers[iones] satelitum Saturnis pergratum is mihi fiet. His me comendo die 28. Decembris.

Po devíti letech mohl tedy Stepling konečně uskutečnit pozorování zákrytů Jupiterových měsíců, o něž jej jménem berlínské akademie věd požádal L. Euler. Konal je od června do ř́ijna 1759 a hlavní údaje z nich poslal Hellovi. Důvod k tomu měl asi dvojí. Jeho styky s Berlínem nebyly v padesátých letech prŕiliš intenzivní, možná i proto, že kurátor akademie věd von Schmettau, který projekt nové mapy Německa vytvořil a staral se o něj, mezitím zemřel. Na druhé straně byl Stepling ve stálém styku s Hellem, který mu opatřil newtonský reflektor i hodiny, jež k pozorování potřeboval. Vedle Hella poslal Stepling výsledky svých pozorování zákrytů Jupiterových měsíců i de Lacaillovi. ${ }^{33}$ Ten za ně poděkoval a slíbil

31 Litterarum commercium, s. 496-500.

32 Wien, Archiv der Universitätssternwarte, Astr._NL_2 154_Correspondentia_1759-16-05.jpg, s. $422 / 14$.

33 Stalo se tak v dopise z 28. dubna 1760: „Adjungo his satellitum Iovis ecclipses recens a me non negligenter observatas." Litterarum commercium, s. 491. 
poslat Steplingovi výsledky obdobných pozorování z Paříže. ${ }^{34}$ Zda se tak skutečně stalo, ale nevíme, jejich korespondence (alespoň ta, kterou uveřejn̆uje Litterarum commercium) zde končí.

Ve výše otištěném listě Hellovi Stepling oznamuje svi̊j záměr vykonat v roce 1760 takovýchto pozorování větší počet a dále je zpřesnit. Váže to však na malou podmínku: že se mu podaří zbavit se funkce ředitele filozofických studií. Skutečností je, že Stepling nechtěl ani na počátku tuto dvousečnou funkci přijmout. K tomu, že ji nakonec přijal, přispěli možná i sami jezuité: mít nad sebou člena vlastního řádu pro ně bylo daleko přijatelnější, než se podřizovat nějaké světské neznámé osobě. Jestliže předběhneme chod událostí: Steplingovi se to podařilo, ale ne hned a ne úplně: jako ředitel filozofických studií skončil v roce 1762, kdy se stal ředitelem studia matematiky a fyziky. Na závěr dopisu žádá Hella o zaslání výsledků jeho vlastního pozorování. Předpokládá, že vyjdou v Hellových efemeridách, za něž je ochoten zaplatit libovolnou cenu. Končí pak zajímavou poznámkou, že si imerse a emerse Saturnových měsíců neobyčejně oblíbil.

Zmínili jsme se již o tom, že Hellova odpověd' je ze 4. ledna 1760. Srovnal v ní Steplingova data se svými pozorováními učiněnými ve Vídni. Musel přitom pominout Steplingův údaj z 9. ř́ijna, kdy bylo ve Vídni zataženo, a neměl proto podklad pro potřebné srovnání. Stranou ponechal také údaje z 22. června, které se rozešly o více než 13", jež připsal na vrub špatnému prépočtu času. Zbylá tři pozorování však vykazovala velice dobrou shodu, když se jejich rozdíl pohyboval mezi 6" a 7". Zároveň sdělil, že všechny své výsledky otiskne $\mathrm{v}$ efemeridách a Stepling je bude mít k dispozici.

$* * *$

Tímto listem končí Steplingův intenzivní korespondenční styk s vídeňským kolegou. Nově objevené opisy listů zapadly přesně do časových hyátů a vytvořily tak s dosud otištěnými listy pro léta 1757-1760 souvislý blok. Má následující podobu:

$\begin{array}{llcl}\text { Stepling Hellovi } & \text { Pragae } & \text { 30. Januarii 1757 } & \text { Archiv univerzitní hvězdárny Vídeň } \\ \text { Hell Steplingovi } & \text { Viennae } & \text { 9. Februarii 1757 } & \text { Litterarum commercium } \\ \text { Hell Steplingovi } & \text { Viennae } & \text { 13. Julii 1757 } & \text { Litterarum commercium } \\ \text { Stepling Hellovi } & \text { Pragae } & \text { 28. Julii } 1757 & \text { Archiv univerzitní hvězdárny Vídeň } \\ \text { Hell Steplingovi } & \text { Viennae } & \text { 15. Augusti 1758 } & \text { Litterarum commercium } \\ \text { Stepling Hellovi } & \text { Pragae } & \text { 30. Augusti 1758 } & \text { Litterarum commercium } \\ \text { Hell Steplingovi } & \text { Viennae } & \text { 9. Septembris 1758 } & \text { Litterarum commercium } \\ \text { Stepling Hellovi } & \text { Pragae } & \text { 28. Decembris 1759 } & \text { Archiv univerzitní hvězdárny Vídeň } \\ \text { Hell Steplingovi } & \text { Viennae } & \text { 4. Januarii 1760 } & \text { Litterarum commercium }\end{array}$

Jistý styk mezi oběma astronomy existoval i nadále, souvislá korespondence to ale nebyla. Počátkem roku 1762 Hell Steplinga doslova zavalil množstvím pozorovacích dat z roku 1761 posbíraných po celé Evropě. ${ }^{35} \mathrm{~V}$ létě 1777 mu posílá Lambertovo schema slunečních skvrn ${ }^{36}$

34 Tamtéž, s. 494.
35 Tamtéž, s. 501-505.
36 Tamtéž, s. 624-626. 
a zmiňuje se rovněž o satelitu Venuše, který pozoroval manheimský Mayer. ${ }^{37}$ Končí poznámkou o nové hvězdárně na univerzitě v uherské Budě. Mezitím došlo v roce 1768 i k jejich osobnímu setkání v Praze. Dne 2. května do Klementina dorazila po pěti dnech cesty Hellova expedice, ${ }^{38}$ která míŕila na ostrov Wardoe, aby zde pozorovala přechod Venuše přes sluneční disk.

Autoři jsou spokojeni, že mohli přispět k rozšíření znalostí Steplingovy korespondence a žijí v naději, že v př́íších letech se podaří objevit i další jeho listy Hellovi ze šedesátých a sedmdesátých let 18 . století, které evidentně chybějí.

JOSEF SMOLKA - HANS ULLMAIER

\section{Unbekannte Briefe von Joseph Stepling an Maximilian Hell}

\section{ZUSAMMENFASSUNG}

Die Korrespondenz der beiden Direktoren der Universitätssternwarten in Wien und in Prag, Joseph Stepling (1716-1778) und Maximilian Hell (1720-1792), ist von der Gesamtausgabe der Briefe Steplings (Litterarum commercium, Breslau 1782) wohlbekannt. Sie scheint aber ziemlich unausgewogen zu sein: von den sieben Briefen aus der Korrespondenz wurden fünf von Hell, aber nur zwei von Stepling verfasst. Es ist also naheliegend, dass einige Briefe Steplings in der oben erwähnten Gesamtausgabe fehlen. Wo könnten sie liegen? Vielleicht im Archiv der Wiener Sternwarte? Und in der Tat wurden hier drei bisher unbekannte Briefe von Stepling an Hell gefunden. Es sind leider keine Autographen, denn Hell ließ offenbar alle erhaltenen Briefe abschreiben.

Der erste Brief zeigt, dass es der ältere Stepling war - inspiriert durch Hells neuerschienene Ephemeriden -, der diesen Briefwechsel aufgenommen hatte. Er bestellt hierin auch für die Prager Sternwarte ein Newtonsches Fernrohr und zwei Grahamsche Ankeruhren aus Wien. Im zweiten Brief bedankt sich Stepling schon für die Besorgung und für das Erproben des Fernrohrs. Weiter bittet er als Direktor des Prager philosophischen Studiums um einen Rat, wie in der folgenden Angelegenheit vorzugehen sei: während des siebenjähriges Krieges standen vor Prag preußische Truppen, die Schulen waren von verwundeten Soldaten überfüllt, mehrere Monate wurde nicht unterrichtet. Stepling glaubt, dass das ganze Schuljahr wiederholt werden sollte, er möchte aber, dass dieses Problem der Kaiserin zur Entscheidung vorgelegt würde. In dem dritten Brief schickt Stepling seinem Jesuitenkollegen die Resultate seiner Beobachtungen der Jupiter-Mondfinsternisse.

Die unlängst entdeckten Briefe passen genau in die Zeitlücke der veröffentlichten Korrespondenz zwischen Stepling und Hell, sodass sie mit den für den Zeitraum 1757-1760 schon früher bekannten Briefen einen konsistenten und vollständigen Block vorstellen.

Deutsch vom Verfasser, Korrektur von Wolf B. Oerter

Josef Smolka

Historický ústav $A V \check{C} R$, emeritní pracovnik

smolkajosef@gmail.com

Hans Ullmaier

emeritní badatel, Jülich / Stockerau, Österreich

hullmaier@gmail.com

37 Hell této zprávě př́iliš nedůvěřoval, považoval pozorovaný jev za nějakou stálici či za optický klam. Jinak Stepling: ten uvěřil už na počátku své vědecké dráhy pozorování Jamese Shorta z roku 1741 a ještě o 22 let později věnoval domnělému Venušinu měsíci zvláštní kapitolku ve svých Miscellaneorum philosophicarum continuatio.

38 Blíže o této události Carl Ludwig Litrrow, P. Hell's Reise nach Wardoe bei Lappland und seine Beobachtung des Venus-Durchganges im Jahre 1769, II. Abt., Wien 1835, s. 87-88; dále Zdislav Š́mA, Astronomie a Klementinum, Praha 2006, s. 37-39. 